\title{
Discourses of Sustainable Finance Implementation in Islamic Bank (Cases Studies in Bank Mandiri Syariah 2018)
}

\author{
Lucky Nugroho $^{1}$, Ahmad Badawi $^{1} \&$ Nurul Hidayah ${ }^{1}$ \\ ${ }^{1}$ Faculty of Economics and Business, Universitas Mercu Buana, Jakarta, Indonesia \\ Correspondence: Lucky Nugroho, Faculty of Economics and Business, Univeristas Mercu Buana, Jl Meruya Selatan \\ No.1, Jakarta Barat, Jakarta, Indonesia.
}

Received: July 2, 2019

doi:10.5430/ijfr.v10n6p108
Accepted: August 9, 2019

Online Published: August 18, 2019

URL: https://doi.org/10.5430/ijfr.v10n6p108

\begin{abstract}
The execution of sustainable finance (SF) in Islamic Bank (Sharia Bank) should be fused with financial products and services due to the compatibility of SF programs with Sharia rules. This article points to define the progress of SF implementation in the Bank Mandiri Syariah before the mandatory to implement regulation from financial Services Authority No. 1/POJK. 3/2017. The method used is qualitative and confined with the following research question (1) What is the precedence of the Government in implementing sustainable finance by regulation No. 51/POJK. 03/2017? (2) How is the progress of sustainable financial implementation on sharia banks during the period of 2018 ? According to the results of the study through secondary data from financial statements, annual reports, and the company's internal data. The Bank Mandiri Syariah has implemented SF during 2018 with the well-presented portion of SF financing ratio from total financing amounting to 29.56\%. Beside of that Bank Mandiri Syariah also already established the sustainable finance plan for five years (2019-2014). Nevertheless, to increase the community trust in Sharia banks regarding the suitable implement of SF in the future. The Islamic Bank need to ensure the commit from all stakeholders to make sharia products and services that implant in the SF program.
\end{abstract}

Keywords: Islamic bank, sustainable finance, Sharia principles

\section{Introduction}

Contamination and environmental damage are essential events in growing nations such as Indonesia. Indonesia has a problem with environmental sustainability, especially air pollution. Air pollution in Indonesia, especially Jakarta as a city that includes the most robust air pollution in the world (Anshory \& Resosudarmo, 2018; Arafah et al., 2018; Kusminingrum \& Gunawan, 2008). Furthermore, referring to data published by kompas.com (February 6, 2018), the air pollution threshold in Jakarta has been alarming and threatens human health. Grounded along the effects of the air quality monitor, the fine dust particles PM2.5 in Jakarta reached above $38 \mu \mathrm{g} / \mathrm{m}^{3}$, can even reach $100 \mu \mathrm{g} / \mathrm{m}^{3}$ on certain days. While the safe limit of excellent dust PM 2.5 that can be inhaled by humans refers to the World Health Organization (WHO) is $25 \mu \mathrm{g} / \mathrm{m}^{3}$. Hence, according to data from the air quality index using air quality monitoring applications, Jakarta is an unfriendly city to become a space to survive due to harmful air pollution and Jakarta including number 3 in the world shown in the table 1.1 below:

Table 1. Air quality index of cities in the world

\begin{tabular}{lll}
\hline Country & Ranking & Air Quality Index \\
\hline Kuwait City, Kuwait & 1 & 211 \\
\hline Hanoi, Vietnam & 2 & 163 \\
\hline Jakarta, Indonesia & 3 & 161 \\
\hline Beijing, China & 4 & 159 \\
\hline Chengdu, China & 5 & 144 \\
\hline Dubai, United Arab Emirates & 6 & 134 \\
\hline
\end{tabular}




\begin{tabular}{lll}
\hline Kolkata, India & 7 & 131 \\
\hline Mumbai, India & 8 & 121 \\
\hline Lahore, Pakistan & 9 & 121 \\
\hline Shanghai, China & 10 & 110 \\
\hline Busan, South Korea & 11 & 102 \\
\hline Los Angeles, USA & 12 & 102 \\
\hline
\end{tabular}

Source: beritagar.id (2018)

Established on the data in Table 1 above, Indonesia has worse air pollution compared to Beijing, China, and Kolkata, India. The high pollution in Indonesia indicates that air pollution in Jakarta has exceeded cities in the world that have more population such as Beijing and Kolkata. Presently, in the universe, it is also experiencing climate change that impacts global warming so that the whole world now has joint programs and actions to aid each other called the Sustainable Development Goal (SDGs). The subject of sustainability has now become a popular event for the world community to get all stakeholders around the globe receive a shared consignment. The joint involvement is to carry out activities and business activities that are oriented towards long-term goals to embedded three interests, namely economic interests, social interests, and environmental interests (Elkinjton, 1998; Slaper \& Hall, 2011).

Therefore, the balance between these three interests (economics, social and environmental) has become the focus of attention of world leaders to implement Sustainability and the need for contributing and anticipatory steps towards climate change. The several important events that have become milestones in the evolution of sustainability topics:

1. Kyoto Protocol, in December 1997, namely the existence of agreement from 141 countries in the world to dilute emissions from glass buildings;

2. The Millennium Summit in New York, in September 2000, was the declaration of the Millennium Development Goals (MDGs) signed by 147 state leaders to implement 8 development goals that until 2015 included: (1) tackling poverty and hunger; (2) achieving primary education for all; (3) promoting gender equality and empowering women; (4) reducing child mortality; (5) improve maternal health; (6) fighting HIV/AIDS, malaria and other infectious diseases; (7) ensuring environmental sustainability; (8) and develop global partnerships for development;

3. World Summit on Sustainable Development (WSSD) in Johannesburg, in 2002 which said that each country takes responsibility for sustainable development and poverty that is focused on the plan of implementation that incorporates economic, ecological and social elements based on good governance. Moreover, WSSD also discusses sustainable development and the existence of partnership programs among stakeholders in implementing sustainable growth;

4. United Nations Conference in Bali, Indonesia in December 2007, an affirmation of voluntary willingness Developing countries reduce emissions in a measurable, reported and correct manner, in the context of sustainable growth, backed by technology, funding, and capacity building;

5. The UN resolution on the program of sustainable development goals (SDGs) in October 2015, which is to re-initiate sustainable development programs with 17 development goals instead of the MDGs program that stopped in 2015.

The United Nations (UN) again initiated further steps to safeguard the survival of future generations after the conclusion of the Millennium Development Goals (MDGs). These steps include the issuance of resolution number A/Res/70/1 on October 21, 2015, in which the United Nations invites all the world community to contribute to Sustainable Development through 17 (seventeen) main objectives, hereinafter referred to as Sustainable Development Goals ( SDGs) which includes: (1) No poverty; (2) Zero hunger; (3) Good health and well-being; (4) Quality education; (5) Gender equality; (6) Clean water and sanitation; (7) Affordable and clean energy; (8) Decent work and economic growth; (9) Industry, innovation and infrastructure; (10) Reduced inequalities; (11) Sustainable cities and communities; (12) Responsible consumption and production; (13) Climate action; (14) Life below water; (15) Life on land; (16) Peace and justice strong institution; (17) Partnerships for the goals.

Furthermore, the banking sector is expected to be able to contribute significantly to the SDGs through actions which embed in the program related to business portfolios and Social and Environmental responsibility activities. This program will also contribute positively to mitigating risks from climate change, reputation risk, legal risk, 
operational risk, and market risk, which will be beneficial for maintaining the banking business in the long run. Strengthening the implementation of Sustainability in the banking sector is supported by the issuance of Regulations by the regulator, in this case, the Financial Services Authority. The regulation from Financial Services Authority (OJK) is POJK No.51/POJK.03/2017 concerning the Implementation of Sustainable Finance for Financial Services Institutions and Public Companies to make and report on Sustainable Financial Action Plans as the implementation of the Sustainable Finance program. Based on these rules, banks have a role in disseminating to their customers to care about sustainability programs or SDGs.

Regarding the main objective of the Sustainable Development Goals (SDGs), sharia banking is an industry that has a close relationship with SDGs (Ahmed, 2011; Nugroho et al., 2018; Chotib \& Utami, 2014). Nevertheless, the implementation of Maqashid Asy Syariah and sharia banking business models that are prohibit from MAGHRIB transaction (Maysir, Gharar, Haram, and Riba) is a form of convergence that is following the whole SDGs (Abdullah, 2018; Masih, Kamil, \& Bacha, 2016; Sukmadilaga \& Nugroho, 2017). Also, currently Sharia Banks (Islamic Banks) are included in the BUKU III category which means the banks with core capital of IDR 5 trillion-IDR 30 trillion and refers to the regulatory provisions that BUKU III Banks are required to implement Sustainable Finance (SF). Therefore, Bank Mandiri Syariah is the only sharia bank in Indonesia that include in Buku III that also to obliged to implement sustainable finance in 2019.

Accompanying the description above, this research aims to find out: (1) Priorities of regulators of the carrying out of sustainable finance under POJK regulation No.51/POJK.03/2017; (2) Progress on the carrying out of sustainable finance for Islamic banks during the period of 2018. Furthermore, the contribution of this inquiry is to bestow to the understanding of sustainable finance in Islamic banking. As well, it also provides input on sustainable financial implementation for Islamic bank management boards, and can likewise lead to further research on sustainable finance in the banking sector. The structure of this report is that in the first segment is related to the background of the implementation of sustainable financial programs. The second segment of the literature study is linked up with the relationship between Islamic banks and sustainable financial program policies. The third part is linked up to the discussion of the research questions in this paper, and the final part is conclusions from the research of the paper.

\section{Literature Review}

This segment will offer a theoretical base on the importance of Islamic banking in implementing sustainable finance so that sustainable finance is an embedded aspect of the rules and objectives of Islamic banks. Islamic banking is an intermediary institution that conducts operational activities based on sharia principles, especially prohibiting the concept of MAGHRIB (Maysir gambling, uncertainty-Gharar transactions, and usury) in financial transactions (Khan, 2010; Sukmadilaga \& Nugroho, 2017). Also, the primary function of Islamic banks is as a solution to the failure of conventional banks as an intermediary which is one of the contributors to the financial crisis because there is an element of greed in carrying out its operational activities (Dowd, 2008; Jalil \& Rahman, 2010; Nugroho, 2014). Nevertheless, Islamic banking is a financial institution that aims to provide benefits or benefits for the entire ummah. Furthermore, Islamic banking is also expected to be able to maintain a balance between the growth of the economy with poverty alleviation, reduce unemployment, improve the quality of health, improve education and also care for environmental sustainability (Dusuki, 2008; Gilani, 2015; Prastowo, 2015; Doktoralina et al., 2018). The balance of sharia principles arises because Islam, as a comprehensive religion, governs all facets of human life, which aims not merely for the benefit of being in the universe but also in the afterlife.

In carrying out its functional activities, Islamic banks must accept the principle of maqasid sharia, which consists of six elements, which include: maintaining religion, protecting lives, protecting reasons, protecting property, protecting offspring, and protecting the environment. Based on this, Islamic banks have significant relationships and responsibilities in realizing a sustainable financial program. It should be noted that a sustainable financial plan is a program that requires financial institutions, including Islamic banks, to be involved in its implementation. Considering the main objectives of the Sustainable Development Goals (SDGs), Islamic banking is an industry that has a close kinship with SDGs. The application of Maqashid Asy Syariah and the sharia banking business model that is spared from MAGHRIB (Maysir, Gharar, Haram, Riba) is a kind of convergence under all SDGs. Grounded on the above and the grandness of the implementation of Sustainable Finance, PT Bank Mandiri Syariah prepares a sustainable financial action plan (RAKB) which holds in the Bank's goals and strategies for implementing Sustainable Financial Action in 2019 founded on the precautionary principle and the prudential principle of banking operations. The RAKB also functions as a guideline for all Bank Work Units to control hazards, primarily social and environmental hazards that may originate at the implementation level of the program. The format of draft RAKB is guided by the Financial Services Authority Regulation (POJK) No.51/POJK.03/2017. Therefore, Islamic banks can 
play a substantial part in efforts to synergize increased business growth while carrying out environmental and social responsibilities guided by the aims of Islamic banks or maqasid sharia.

There is a similarity between the vision and mission of Islamic banks with the government's plan to implement the principle of sustainable finance, namely where Islamic banks in carrying out business activities have the principle of "Sustainability Sharia Banking Principle." Sustainability Sharia Banking Principle is a sustainable business principle based on a balance of aspects of the world and hereafter (Falah). The sustainable business rules of the Bank must be touched to the symmetry of elements of the world; economic, societal, and environmental aspects in a holistic and afterlife perspective. The role of the Sustainability Sharia Banking Principles is to preserve the sustainability of the Syariah Bank in achieving a vision consistently based on the rules of prudent banking and sharia comply covering aspects: Sharia Principles, Customers, Business Strategy, Banking Operations, Risk Management, Human Capital, Community Development and environment aspects. If illustrated, the maqasid sharia relationship with the implementation of sustainable finance is as follows:

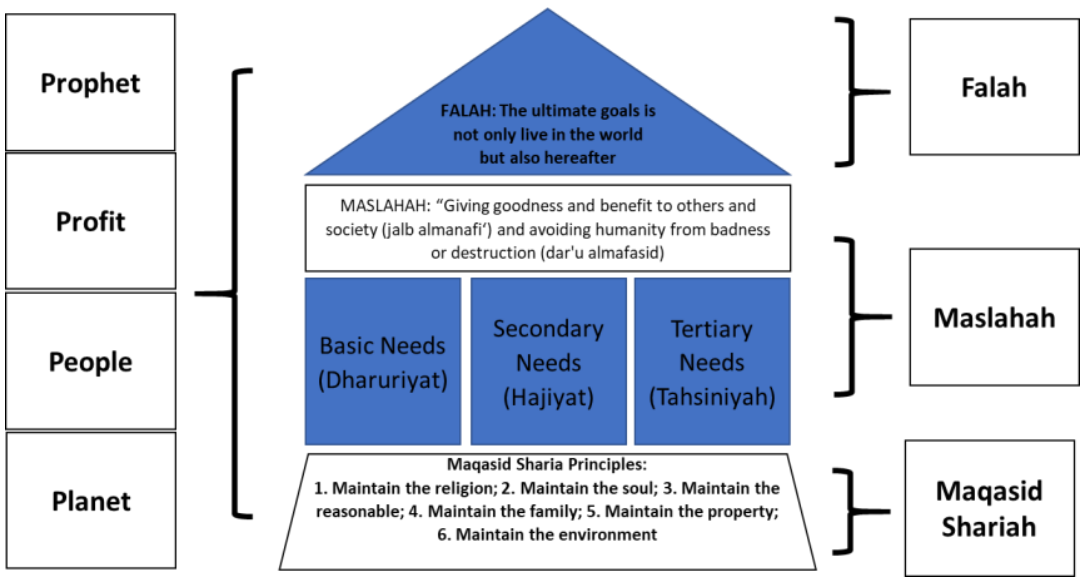

Figure 1. Sustainable finance Sharia banking principles

Source: Own

By Figure 1 related to the Sustainability Sharia Banking Principle, according to Nugroho, Hidayah \& Badawi (2018), Islamic banks in their operations have three principles, which include:

- Falah: The creation of civic order, namely civilization (fulfillment of the physical-scientific and technological aspects) and tsaqafah (realization of the Spiritual-Faith aspect) which is backed by the sharia financial ecosystem;

- Maslahah: The existence of Islamic banks is to offer benefits (benefit) for the ummah;

- Maqasid Sharia: The function of Islamic banks is to preserve religion, maintain the soul, maintain reason, maintain offspring, safeguard property, and protect the environment.

The maqasid sharia is implemented in daily human life activity, namely in meeting basic needs, secondary needs and tertiary needs so that sharia banking services in supporting human life in business and financial transactions need to have the same vision and mission. The vision and mission must be based on sharia maqasid, which aims to achieve benefit and Falah. Also, Islamic banking with its prophet pillars, profits, people and planet is to maintain a balance between business profits that have moral and spiritual responsibilities and have an impact on reducing social problems such as poverty, unemployment, and social inequality.

Several previous studies said that the implementation of green banking had been held away before the issuing of the ordinance of the POJK Financial Services Authority (OJK) No.51/POJK.03/2017 concerning the Implementation of Sustainable Finance for Financial Service Institutions, Issuers, and Public Companies so that the application of green banking was still voluntary. Research related to green banking always refers to the general rules of UNEP - the United Nations Environment Program Finance Initiative, 2011 conducted by Baskoro \& Santoso (2015) and Aji \& Aisyah, (2016). While the research conducted by (Nugroho et al., 2017) focuses on micro-entrepreneurs, who become customers of microfinance institutions that have the prospect of damaging the environment. Based on previous studies, there are no researchers who have analyzed the application of POJK No.51/POJK.03/2017 
concerning the Implementation of Sustainable Finance in Islamic banks. An organization or company must have an excellent performance so that it can give confidence to all stakeholders or stakeholders on the sustainability of the company's business operations. Nevertheless, according to Peloza (2012) with excellent corporate financial performance (CFP), it will improve the company's reputation before stakeholders, even with an increase in CFP will have an impact on increasing organizational awareness of social responsibility (corporate social responsibility-CSR). In other words, the rise in CFP will affect improving CSR. If the concept is related to the performance measurement of Islamic banks, the financial aspects, social of justice and environment aspects cannot be separated.

\section{Method}

This study explores the regulations related to sustainable finance contained in POJK No.51/POJK.03/2017 and its implementation in Bank Mandiri Syariah. Therefore, this work uses qualitative research with literature studies. In this study, secondary data were obtained from relevant literature such as books, academic research, industry papers, and other sources. Furthermore, this research is limited by the following research questions:

- What are the priorities of the goverment for the carrying out of sustainable finance by the regulation No. 51/POJK.03/2017?

- How is the progress of implementing sustainable finance on Islamic banks during the period 2018?

Established on the research question, the research mechanism is as follows:

- Analyzing OJK Regulation No. 51/POJK.03/017 related to the implementation of Sustainable Finance, what are indicators of the carrying out of sustainable financial programs;

- Examining the progress of sustainable finance application based on indicators from OJK regulation No. 51/POJK.03/2017 at Bank Mandiri Syariah.

Nevertheless, if illustrated, the mechanism of research is as follows:

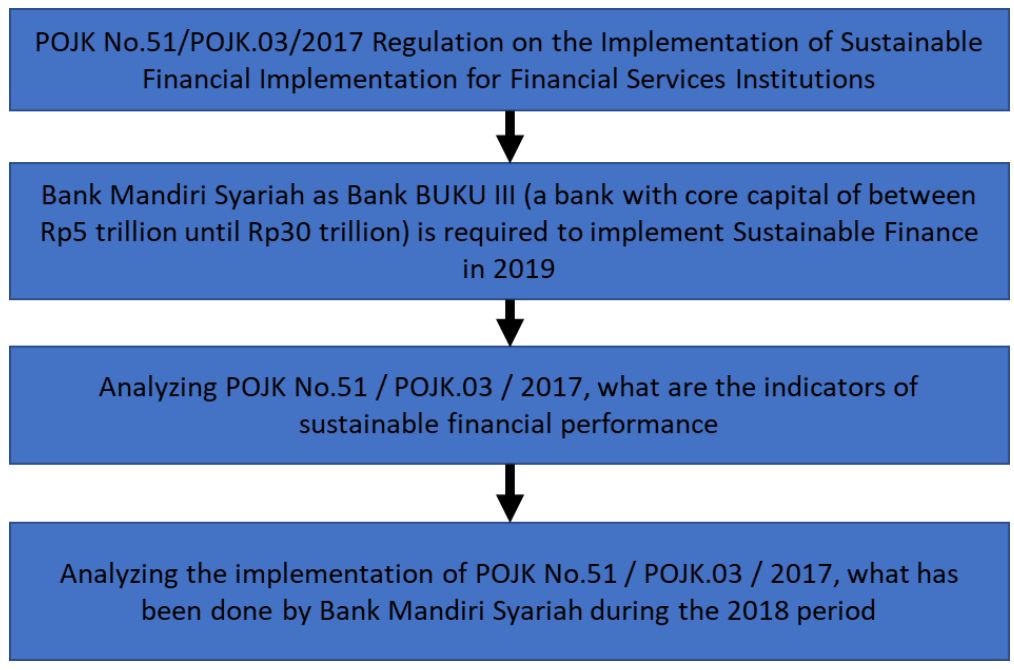

Figure 2. Mechanism of research in this paper

Source: Own

\section{Results and Discussion}

Priorities of the regulator of the implementation of sustainable finance by the regulation No. 51/POJK.03/2017

Sustainable Finance is the integrated support of the financial services sector to produce sustainable economic growth by harmonizing economic, societal, and environmental stakes. Therefore, Bank Mandiri Syariah must implement the provisions referring to sustainable finance. The demands of sustainable finance implementation should throw the following objectives: (1) Provide Financing needed to achieve SDGs; (2) Improve competitiveness through social and environmental hazard mitigation; (3) Decrease social gaps and protect the environment; (4) Develop sustainable finance product/services. The chronology of implementing sustainable finance in Indonesia is as follows: 
- $\quad$ Regulation of OJK No. 51/POJK.3/2017 was launched on July 20, 2017, and is valid from January 2019 for foreign banks and bank Buku IV (national banks that have core capital above Rp30 trillion-such as Bank Mandiri, Bank BRI, Bank BNI, Bank BCA and Bank CIMB Niaga) and are of a voluntary for bank Buku III (a bank that has core capital Rp5 trillion until Rp30 trillion)

- Other financial service institutions and smaller banks that have core capital below Rp 5 trillion will gradually follow the SF regulation until 2025.

Furthermore, so that sustainable financial programs can have an impact on society and the environment, comprehensively the objectives of sustainable financial programs include:

- Availability of funding sources needed to achieve sustainable development goals and funding related to climate change in an adequate amount;

- Increasing the resilience and competitiveness of financial service institutions, and Public Companies through better management of social and Environmental risks by developing financial products and/or services that apply the principle of Sustainable Finance so that they have a positive impact on financial system stability;

- Engage and support activities related to reducing social inequalities, reducing and preventing damage to the environment, safeguarding biodiversity, and promoting efficient use of energy and natural resources;

- Develop financial products and/or services that apply the principle of Sustainable Finance.

The application of sustainable finance also focuses on the fund portfolio as well as financing distribution, which has the following categories:

- Renewable energy;

- $\quad$ Energy efficiency;

- Pollution prevention and control;

- Sustainable natural resource management and sustainable land use;

- Biodiversity conservation;

- Environmentally friendly transportation;

- Sustainable management of water and wastewater;

- $\quad$ Adaptation to climate change;

- $\quad$ Products that can reduce the use of resources and produce less efficient resources;

- Environmentally sound buildings following national, regional or international standards or certifications;

- Business activities and/or other activities that are environmentally sound;

- UMKM activities that are ecologically concern.

The progress of implementing sustainable finance on Islamic banks (Bank Mandiri Syariah) during the period 2018

The execution of sustainable finance at Bank Mandiri Syariah is still voluntary because BSM is a Bank with BUKU III category, which is compelled to implement sustainable finance in 2019. Nonetheless, because BSM is a sharia bank that carries on business activities, guided and complied with sharia principles, it can It is said that Islamic banks are in concordance with the natural processes of sustainable finance. The suitability of Islamic bank operations with the principle of sustainable finance refers to the principle of maqhasid sharia, maslahah, and falah (Kara, 2012; Rusydiana \& Sanrego, 2018). The principle of maqhasid sharia, maslahah, and falah is a principle that requires Islamic banks to have an orientation not only for profit-oriented but also to improve people's welfare and solve social problems and preserve the environment. BSM business activities throughout 2018 have provided financing with Islamic principles to the community in the amount of Rp67,4 trillion. The component of financing based on the economic sector by Bank Indonesia regulation as the central bank is as follows: 
Table 2. Financing portion of BSM based on economic sector

\begin{tabular}{llllll}
\hline No & Economic Sector & Portion & No & Economic Sector & Portion \\
\hline 1 & Housing Financing & $13.4 \%$ & 11 & Construction Financing & $8.1 \%$ \\
\hline 2 & Apartement Financing & $0.3 \%$ & 12 & Wholesale and Groceries Financing & $5.1 \%$ \\
\hline \multirow{2}{*}{3} & $\begin{array}{l}\text { Commercial Housing } \\
\text { Financing }\end{array}$ & $0.2 \%$ & 13 & Transportation Financing & $3.6 \%$ \\
\hline 4 & Automotive Financing & $2.9 \%$ & 14 & Communicationg Financing & $1.2 \%$ \\
\hline 5 & Household Financing & $0.4 \%$ & 15 & Finance Intermediary Financing & $9.4 \%$ \\
\hline 6 & Consumption Financing & $25.4 \%$ & 16 & Real Estate Financing & $0.9 \%$ \\
\hline \multirow{2}{*}{7} & Agriculture Financing & $5.1 \%$ & 17 & Financing & $2.5 \%$ \\
\hline 8 & Fishery Financing & $0.1 \%$ & 18 & Education Financing & $2.7 \%$ \\
\hline 9 & Mining Financing & $1.8 \%$ & 19 & Health and Social Acitivities Financing & $3.6 \%$ \\
\hline 10 & Industry Financing & $11.4 \%$ & 20 & Social, Culture and Entartainment Financing & $1.9 \%$ \\
\hline
\end{tabular}

According to the Table 2 above, the financing distributed to the majority in the consumer sector. This phenomenon can be an evaluation of financing from sharia banks because sharia banks must be capable to contribute significantly to the real sector focused on productive financing (Dyatama \& Yuliadi, 2015; Nasution, 2016). Furthermore, to analyze the financing distribution that complies with the category of sustainable finance, it is made a portion of the BSM financing distribution with financing that meets the criteria of sustainable finance (SF). The results portions of SF channeling are as follows:

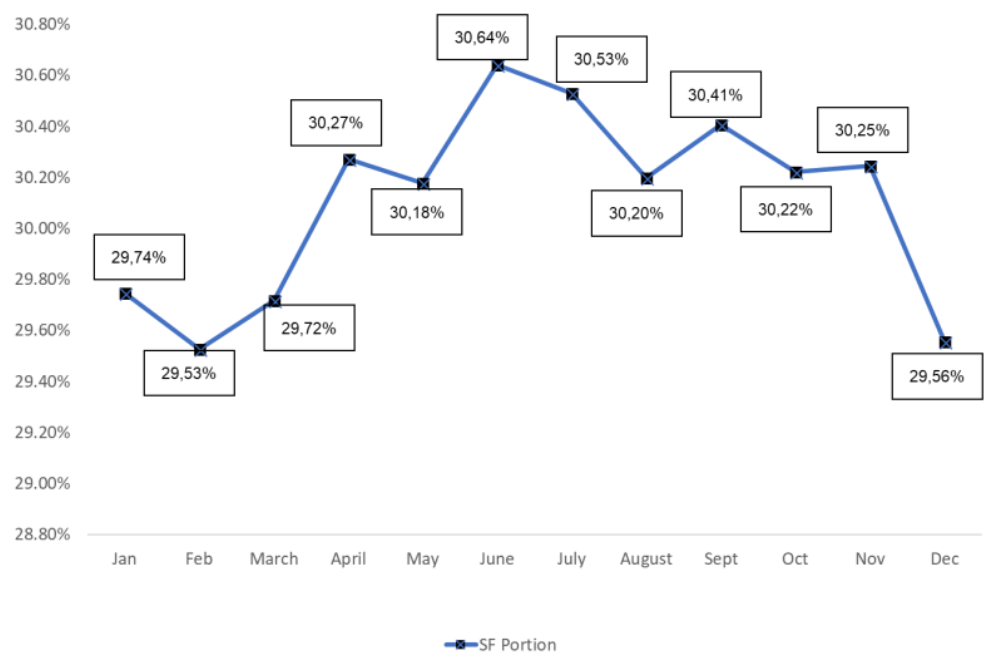

Figure 3. SF portion on BSM financing

By Figure 3 above, it is known that Bank Mandiri Syariah has channeled financing that meets the SF criteria with a distribution above $25 \%$ every month. This is in line with the commitment of Islamic banks, namely, to make a significant contribution to the settlement of social problems, both in the economic aspects, health aspects, and education aspects. In addition to concern for Islamic banks to social issues, Islamic bank also concerns related to the preservation of the environment, which is also included in the component SF. Further, to analyze the monthly growth of SF financing distribution, it can be shown on the Figure 4 and Table 3 below: 


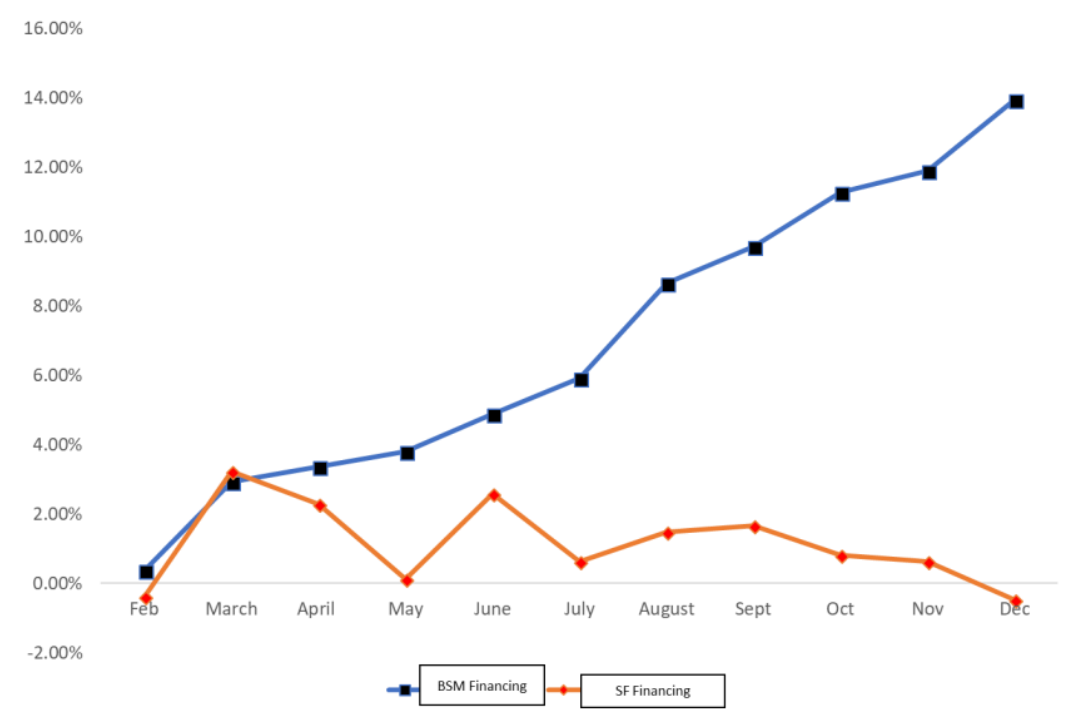

Figure 4. Growth of SF financing VS BSM financing

Table 3. Growth of SF financing VS BSM financing

\begin{tabular}{lll}
\hline Growth & BSM Financing & SF Financing \\
\hline Feb & $0.37 \%$ & $-0.38 \%$ \\
\hline Mar & $2.93 \%$ & $3.22 \%$ \\
\hline Apr & $3.36 \%$ & $2.29 \%$ \\
\hline May & $3.81 \%$ & $0.12 \%$ \\
\hline Jun & $4.88 \%$ & $2.58 \%$ \\
\hline Jul & $5.93 \%$ & $0.63 \%$ \\
\hline Aug & $8.67 \%$ & $1.47 \%$ \\
\hline Sep & $9.72 \%$ & $1.67 \%$ \\
\hline Oct & $11.29 \%$ & $0.82 \%$ \\
\hline Nov & $11.90 \%$ & $0.62 \%$ \\
\hline Dec & $13.95 \%$ & $-0.48 \%$ \\
\hline
\end{tabular}

Referring to the Figure 4 and Table 3, the growth of BSM financing has not been accompanied by increased growth of SF financing, although the portion of the SF distribution is good enough that more than $25 \%$ of the BSM financing portfolio has fulfilled SF criteria (Figure 3). The commitment to SF implementation in the early phases of the sharia bank is quite right, as the SF financing portion is over $25 \%$ and there has been a sustainable financial action plan for the period of 2019-2024. In order to run the SF implementation, it requires the understanding and commitment of all employees and stakeholders from sharia banks to the importance of SF for the benefit of the Ummat. However, it is necessary to have special attention related to the SF distribution trend which has not been in line with BSM financing growth, where BSM financing tends to increase, while the SF program is experiencing a downward trend (Figure 4 and Table 3). The reduction was due to the absence of extra instruments to monitor the progress of the SF program and also found no similarity in perceptions and commitment to the grandness of the SF program. Should all stakeholders of Sharia banks realize that the long-term implementation of SF programs will improve people's wellbeing and prevent climate change from occurring (Rolffs, Ockwell, \& Byrne, 2015; Steckel et al., 2017). Further $\mathrm{SF}$ implementation in Sharia banks is proof that sharia banks are by sharia principles and contribute to the wellbeing of society. 
In addition, to support the implementation of SF, it needs a specific application to be able to monitor the growth of $\mathrm{SF}$ financing, as well as the risk acceptance criteria (RAC) which is specific to SF in the financing distribution of Sharia banks, key performance indicator (KPI) to measure of performance achievement of every business unit and the most essential is the board management and also shareholder commitment to empowerment SF activities. Therefore, the implementation of SF can be an embedded with financing and other products and services in Sharia banks.

\section{Conclusion}

The sustainable Financial Program (SF) has been followed out by Bank Mandiri Syariah in the period of 2018, although there is no regulation that it. SF implementation in Sharia banks is a must because according sharia principles so that the regulation of OJK No. 51/POJK. 3/2017 on the implementation of sustainable finance for Sharia banks is not an obstacle. Nonetheless, the SF implementation of financial products from Bank Mandiri Syariah in the period of 2018 has reached a portion of $29.56 \%$ of all financing in December 2018. Thus the implementation of SF on sharia banks is good enough. Furthermore, to improve the implementation of the SF program in Islamic banks, it is necessary to understand and commit from all relevant employees and stakeholders about the importance of SF so that SF activities can be integrated with all financial products and services available at Islamic Banks.

This study has limitations related to the short period of observation due to the issuance of new regulations related to $\mathrm{SF}$, and currently, these rules are still voluntary to be implemented. Furthermore, the adoption of SF is part of the principles of sharia, and Islamic banks should commit to the implementation of SF so that this research initiates further research related to SF and Islamic banks in Indonesia.

\section{References}

Abdullah, M. (2018). Waqf, Sustainable Development Goals (SDGs) and maqasid. International Journal of Social Economics, 45(1), 158-172. https://doi.org/10.1108/IJSE-10-2016-0295

Ahmed, H. (2011). Maqasid al-Shari'ah and Islamic financial products: a framework for assessment. ISRA International Journal of Islamic Finance, 3(1), 149-160.

Aji, D., \& Aisyah, N. (2016). Aspek Hukum Penerapan Green Banking Dalam Kegiatan Kredit Di Pt. Bank Negara Indonesia (Persero) TBK. Privat Law, 4(2), 55-62.

Anshory, A., \& Resosudarmo, B. P. (2018). Does clean air matter in developing countries' megacities? A hedonic price analysis of the Jakarta housing market, Indonesia Does clean air matter in developing countries' megacities? A hedonic price analysis of the Jakarta housing market, Indonesia. Ecological Economics, 68(5), 1398-1407. https://doi.org/10.1016/j.ecolecon.2008.09.011

Arafah, W., Nugroho, L., Takaya, R., \& Soekapdjo, S. (2018). Marketing strategy for renewable energy development in Indonesia context today. International Journal of Energy Economics and Policy, 8(5), 181-186.

Baskoro, R. E., \& Santoso, H. (2015). Analisis Penerapan Sustainabilitas Bank Hijau Pada Bank Pendahuluan Metode Penelitian. Industrial Engineering Online Journal, 4(4), 1-10.

Chotib, A., \& Utami, W. (2014). Studi Kinerja PT BNI Syariah Sesudah Pemisahan (Spin Off) dari PT Bank BNI (Persero) TBK. Akuntabilitas, 7(2), 94-108.

Doktoralina, C. M., Bahari, Z., Herliansyah, Y., Ismail, N. A., \& Putri, P. P. (2018). Role of Accounting Zakat as a Support Function in Supply Chain Management: A Resurrection of the Islamic Economy. International Journal of Supply Chain Management, 7(5), 336.

Dowd, K. (2008). Moral Hazard and the Financial Crisis. Cato J, 29, 141-166.

Dusuki, A. W. (2008). Banking for the poor: the role of Islamic banking in microfinance initiatives. Humanomics, 24(1), 49-66. https://doi.org/10.1108/08288660810851469

Dyatama, A. N., \& Yuliadi, I. (2015, April). Determinan Jumlah Pembiayaan. Jurnal Ekonomi \& Studi Pembangunan, $16,73-83$.

Elkinjton, J. (1998). Partnerships from cannibals with forks: The triple bottom line of 21st-century business. Environmental Quality Management, 8(1), 37-51. https://doi.org/10.1002/tqem.3310080106

Gilani, H. (2015). Exploring the ethical aspects of Islamic banking. International Journal of Islamic and Middle Eastern Finance and Management, 8(1), 85-98. https://doi.org/10.1108/IMEFM-09-2012-0087 
Jalil, A., \& Rahman, M. K. (2010). Financial Transactions in Islamic Banking are Viable Alternatives to the Conventional Banking Transactions. International Journal of Business and Social Science, 1(3), 219-233.

Kara, M. (2012). Pemikiran Al-Syatibi Tentang Maslahah dan Impelementasinya Dalam Pengembangan Ekonomi Syariah. Assets, 2(2), 173-184.

Khan, F. (2010). How 'Islamic' is Islamic Banking ?. Journal of Economic Behavior \& Organization, 76(3), 805-820. https://doi.org/10.1016/j.jebo.2010.09.015

Kusminingrum, N., \& Gunawan, G. (2008). Polusi udara akibat aktivitas kendaraan bermotor di jalan perkotaan pulau jawa dan bali. Jurnal, Jakarta, Puslitbang Jalan Dan Jembatan.

Masih, M., Kamil, N. K. M., \& Bacha, O. I. (2016). Issues in Islamic Equities : A Literature Survey Issues in Islamic Equities: A Literature Survey. Emerging Markets Finance and Trade, 54(1), 1-26. https://doi.org/10.1080/1540496X.2016.1234370

Nasution, Z. (2016). Model Pembiayaan Syariah untuk Sektor Pertanian. Jurnal Ekonomi \& Perbankan Syariah, 3(2), 324-343. https://doi.org/10.19105/iqtishadia.v3i2.1081

Nugroho, L. (2014). Role of Government Support to Micro Financing in Islamic Bank for Clean Water Connection to Low-Income Communities Role of Government Support to Micro Financing in Islamic Bank for Clean Water Connection to Low-Income Communities. Research Journal of Finance and Accounting, 5(4), 57-63.

Nugroho, L., Hidayah, N., \& Badawi, A. (2018). The Islamic Banking, Asset Quality: "Does Financing Segmentation Matters" (Indonesia Evidence). Mediterranean Journal of Social Sciences, 9(5), 221-235. https://doi.org/10.2478/mjss-2018-0154

Nugroho, L., Utami, W., Akbar, T., \& Arafah, W. (2017). The challenges of microfinance institutions in empowering micro and small entrepreneur to implementating green activity. International Journal of Energy Economics and Policy, 7(3).

Peloza, J. (2012). Using Corporate Social Responsibility as Insurance for Financial Performance. California Management Review, 48(2), 52-72. https://doi.org/10.2307/41166338

Prastowo, N. L. (2014). The Challenges of Islamic Microfinance (Indonesia Evidence). European Journal of Islamic Finance, (1), 1-7. https://doi.org/10.13135/2421-2172/793

Rolffs, P., Ockwell, D., \& Byrne, R. (2015). Beyond technology and finance: pay-as-you-go sustainable energy access and theories of social change. Environment and Planning, 47(12), 2609-2627. https://doi.org/10.1177/0308518X15615368

Rusydiana, A., \& Sanrego, Y. D. (2018). Measuring the Performance of Islamic Banking in Indonesia: an Application of Maslahah-Efficiency Quadrant (Meq). Journal of Islamic Monetary Economics and Finance, 3, 103-130. https://doi.org/10.21098/jimf.v3i0.909

Slaper, T. F., \& Hall, T. J. (2011). The Triple Bottom Line: What Is It and How Does It Work?. Indiana Business Review, 86(1), 4-8.

Steckel, J. C., Jakob, M., Flachsland, C., \& Kornek, U. (2017). From climate finance toward sustainable development finance. Wiley Interdisciplinary Reviews: Climate Change, 8(1), 437. https://doi.org/10.1002/wcc.437

Sukmadilaga, C., \& Nugroho, L. (2017). Pengantar Akuntansi Perbankan Syariah" Prinsip, Praktik dan Kinerja. (P. Media, 1st ed.). Lampung, Jakarta: Pusaka Media.

\section{Online References}

https://megapolitan.kompas.com/read/2018/12/06/17291931/dianggap-lalai-tangani-polusi-udara-anies-hingga-joko wi-akan-digugat

https://beritagar.id/artikel/berita/jakarta-harus-belajar-dari-tiongkok-untuk-atasi-polusi-udara 